\title{
Estimating Grass Yield on Blue Grama Range From Seasonal Rainfall and Soil Moisture Measurements
}

\author{
L. Allen Torell, ${ }^{1}$ Kirk C. McDaniel, ${ }^{2}$ and Victor Koren ${ }^{3}$ \\ Authors are ${ }^{1}$ Professor, Department of Agricultural Economics and Agricultural Business and ${ }^{2}$ Professor, Department of Animal and Range Sciences, New \\ Mexico State University, Las Cruces, NM 88003, USA; and ${ }^{3}$ Senior Research Hydrologist, Office of Hydrologic Development, National Oceanic and \\ Atmospheric Administration, National Weather Service, Silver Spring, MD 20910, USA.
}

\begin{abstract}
To estimate annual forage production from moisture conditions it is important to consider the timing and seasonality of precipitation events as well as the past history of storm events. In this study we examined this relationship using $16 \mathrm{yr}$ of annual measurements of herbaceous standing crop recorded at two study sites located on the Corona Range and Livestock Research Center in central New Mexico. Our hypothesis was that end-of-season herbaceous standing crop estimations could be improved using measured soil moisture instead of seasonal accumulations of rainfall as traditionally used for yield prediction. Daily recorded and simulated soil moisture levels were used to estimate the number of days over the growing season when soil moisture by volume was at low $(<20 \%)$, intermediate $(20 \%$ to $30 \%)$, or high $(\geq 30 \%)$ levels. Defining regression equations to include either simulated or probe-recorded measures of soil moisture improved the adjusted $R^{2}$ of the regression models from $46 \%$ for the rainfall model to over $60 \%$ for various soil moisture models. Key variables for explaining annual variation in herbaceous production included seasonal moisture conditions, the amount of broom snakeweed (Gutierrezia sarothrae [Pursh] Britt. \& Rusby) present on the area, and the degree days of temperature accumulated over the growing season. Diurnal daily temperatures near historical averages were most advantageous for forage production. Simulated soil moisture data improved predictive grass yield estimates to a level equivalent to using onsite moisture probes to categorize daily moisture conditions. Potential exists to better predict forage conditions based on forecast information that uses soil moisture data instead of the traditional input of seasonal rainfall totals.
\end{abstract}

\section{Resumen}

Para estimar la producción anual de forraje basándose en las condiciones de humedad es importante tener en cuenta la época y la distribución de las precipitaciones, así como el pasado histórico de las mismas. En este estudio examinamos esta relación utilizando 16 años de mediciones anuales de la producción de la biomasa aérea en dos sitios localizados en el Corona Range and Livestock Research Center (CRLRC) en la parte central de New México. Nuestra hipótesis fue que las estimaciones al final de la época de crecimiento de la producción de biomasa aérea se pueden mejorar utilizando la humedad del suelo en lugar de la precipitación acumulada durante la estación como se ha utilizado tradicionalmente para la predicción de la producción. Niveles de humedad del suelo registradas y simuladas se utilizaron para estimar el número de días en la estación de crecimiento cuando la humedad del suelo por volumen es baja $(<20 \%)$, intermedia $(20 \%$ a $30 \%)$ o alta $(\geq 30 \%)$. Para definir la ecuación de regresión para incluir las medidas simuladas o las registradas de la humedad del suelo, mejoraron la $R \mathrm{P}^{2} \mathrm{P}$ ajustada de los modelos de regresión del $46 \%$ para el modelo de la precipitación a más de $60 \%$ para varios modelos de humedad del suelo. Las variables principales que se incluyeron para explicar la variación anual en la producción herbácea fueron, las condiciones de humedad estacional, la cantidad de escobilla (Gutierrezia sarothrae (Pursh) Britt. \& Rusby) presente en el área y los días con grado de temperatura acumulada durante la estación de crecimiento. Las temperaturas diarias cercanas a los promedios históricos fueron las de más utilidad para producción de forraje. Los datos simulados de la humedad del suelo mejoraron las estimaciones del rendimiento de las gramíneas a un nivel equivalente al uso de sondas de humedad en el sitio para categorizar diariamente las condiciones de humedad. Existe la posibilidad de predecir mejor las condiciones de forraje, basándose en la predicción climática que usa datos de humedad en lugar de la medida tradicional de la precipitación total.

Key Words: biomass prediction model, Bouteloua gracilis, climate, modified Sacramento soil moisture accounting model, precipitation, rangeland net primary production (NPP), soil water-NPP relationships

Research was supported by New Mexico State University's Agricultural Experiment Station under a US Department of Agriculture Cooperative State Research Service special grant for Rangeland Ecology Research and a State of New Mexico legislative appropriation for broom snakeweed research. Assistance and funding were also provided by the National Oceanic and Atmospheric Administration, National Weather Service Office of Hydrologic Development, contract DG131W05BU1035.

Correspondence: L. Allen Torell, Dept of Agricultural Economics, New Mexico State University, PO Box 30003, MSC 3169, Las Cruces, NM 88003, USA. Email: atorell@nmsu.edu

Manuscript received 19 July 2009; manuscript accepted 29 August 2010.

\section{INTRODUCTION}

Precipitation and available soil moisture are recognized as the most important environmental factors influencing annual production on rangelands (Vallentine 1990). Numerous studies have related herbaceous production to seasonal and annual precipitation amounts (Nelson 1934; Sneva and Hyder 1962; Pieper et al. 1971; Cable 1975; Khumalo and Holechek 2005; Smart et al. 2007), though success in explaining the production 
relationship has been shown to depend on the scale of analysis. Sala et al. (1988) found when analyzing data collected at 9500 sites in the central United States that variability in grassland primary production at the regional scale could be accounted for by a single variable, annual precipitation amount $\left(r^{2}=0.90\right)$. At the individual site level, additional detail about plant community composition, slope, rangeland health, and land use practices improves vegetative predictive models (Cable 1975; Briggs and Knapp 1995; Andales et al. 2006). Additionally, as noted by Sala et al. (1988), soil characteristics are important in explaining plant production differences at the site level but are overshadowed by climate at the regional scale.

Research on herbaceous production and precipitation relationships in the southwestern United States have been reported by Pieper et al. (1971), Cable (1975), McDaniel et al. (1993), and Khumalo and Holechek (2005). These studies consistently found end-of-season standing crop yields to be most strongly correlated with growing-season precipitation. If a particular month was selected, then August precipitation was most important for yield prediction (Cable 1975). Winter precipitation reportedly contributes little to grass production in the semidesert Southwest (Cable 1975); however, although not well studied, previous summer and fall precipitation may play a role in the following year's perennial grass production. Cable (1975) described this importance as the improved health, carbohydrate storage, and bud enlargement of forage plants when moisture conditions were favorable the previous year.

Though previous studies have related herbaceous production to seasonal or annual rainfall totals, it is generally assumed that soil moisture provides a more useful and robust measure than precipitation alone for estimating plant growth on rangelands (Andales et al. 2006). Each unit of precipitation is not equally effective in producing new plant growth: small rains may evaporate quickly, large amounts may run off, and soil already filled to capacity cannot store additional water. However, Cable (1975) found size and spacing of storms were so highly correlated with each other, and with total precipitation, that little benefit was obtained by including this information in predictive equations. Direct soil moisture measurements should capture these important attributes and offers an improved composite explanatory variable for explaining annual variation in grass production. Yet, because of the laborious task of gathering estimates of soil water content, few studies have directly examined the influence soil moisture has on range forage production. Exceptions include an early study by Rogler and Haas (1947), which considered the importance of autumn soil moisture for predicting forage production the next growing season. Dahl (1963) conducted a similar study at Akron, Colorado, and reported that the depth of moist soil during the spring was a useful measure for predicting accumulated grass yields for early season stocking decisions. Briggs and Knapp (1995) found the amount of net primary production (NPP) variation explained by regressions that combined meteorological variables with soil moisture values increased by $<10 \%$. The authors concluded that the contention made by Sala et al. (1988) that at the site level significantly more of the variance in NPP would be explained by adding additional soil moisture variables was not supported.

When automated weather recording devices like those used by Briggs and Knapp (1995) became available in the early 1990s, this expanded the potential to quantify how plant production relates to environmental conditions. Time domain reflectory (TDR) probes coupled with a recording device provide one means of obtaining a continuous hourly and daily record of soil moisture conditions at different depths throughout the soil profile. In this study we compared the use of soil moisture and seasonal precipitation data for predicting end-ofseason standing crop on blue grama (Bouteloua gracilis [Kunth in H. B. K.] Lag. ex Griffiths) range in central New Mexico. Our objective was to compare traditional prediction of grass yield using accumulated seasonal rainfall amounts vs. other models that used number of days with alternative levels of soil water content as the moisture explanatory variable. The hypothesis tested is that incorporating measurements of soil moisture instead of seasonal rainfall totals will improve end-ofgrowing-season herbaceous standing crop predictions. Other secondary explanatory variables in the analysis included diurnal air temperature and the amount of broom snakeweed (Gutierrezia sarothrae [Pursh] Britt. \& Rusby) present.

\section{MATERIALS AND METHODS}

\section{Study Sites and Environmental Setting}

Vegetative and climatological data for this study were gathered at two locations about $4 \mathrm{~km}$ apart over a 17 -yr period (19902006) on the New Mexico State University Corona Range and Livestock Research Center (CRLRC), which is located $23 \mathrm{~km}$ northeast of Corona, New Mexico (lat $34^{\circ} 15^{\prime} \mathrm{N}$, long $\left.105^{\circ} 24^{\prime} \mathrm{W}\right)$. Data were gathered, in part, from other studies investigating burning and herbicide control alternatives for broom snakeweed (McDaniel et al. 1997, 2000). The study sites occupied similar level topography $(<5 \%$ slope $)$ with uniform vegetation described by the US Department of Agriculture Soil Conservation Service (1987) as within the blue grama-western wheatgrass (Pascopyrum smithii [Rydb.] A. Löve) association. Blue grama was the principal graminoid species, and western wheatgrass was only a rare cool-season component. Broom snakeweed was dominant when the study was initiated and was uniformly distributed across both study areas. Other minor grass species included wolftail (Lycurus phleoides [H. B. K.]), sand dropseed (Sporobolus cryptandrus [Torr.] A. Gray), squirrel tail (Elymus longifolius [Smith] Gould), galleta (Pleuraphis jamesii Torrey), ring muhly (Mublenbergia torreyi [Kunth] A. S. Hitchcock ex Bush), and threeawns (Aristida spp.). Scattered cacti included cane cholla (Cylindropuntia imbricata [Haworth] F. M. Knuth) and plains prickly-pear (Opuntia phaeacantha Engelmann); shrubs included winterfat (Krascheninnikovia lanata [Pursh] A. D. J. Meeuse \& Smit), and Bigelow sage (Artemisia bigelovii Gray).

Soils on both study sites were of the Tapia-Dean association, which are shallow and underlain by highly calcareous limestone bedrock (shallow limestone ecological site). The Tapia loam is a brown medium-textured clay loam with a surface layer that is about $10 \mathrm{~cm}$ deep, which grades into a subsoil at about $50 \mathrm{~cm}$ to very limy caliche. The Dean loam's surface layer is a light brownish-gray limy loam that is not as deep as the Tapia loam. Most plant roots are confined to the surface layer and the subsoil. Water storage capacity for this soil association is low to moderate (Bowman et al. 1970). 


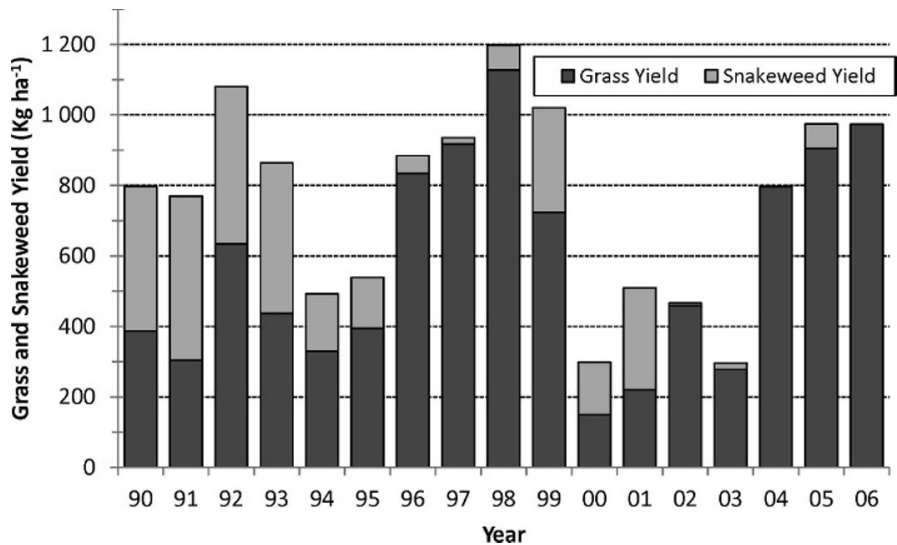

Figure 1. Average end-of-season grass and snakeweed yield $\left(\mathrm{kg} \cdot \mathrm{ha}^{-1}\right)$ on control treatment areas at the two study sites, 1990 2006.

Study sites were placed within 8-ha fenced livestock enclosures, and livestock grazing did not occur within the fenced areas over the study period. Natural herbivory by insects, deer, rodents and other animals was evident. Prior to this study, both sites were grazed with an unknown history by cattle and sheep.

In the experimental design used by McDaniel et al. (1997, 2000), broom snakeweed burn and herbicide control treatments with untreated controls were placed in a completely randomized design with treatments replicated three times on $20 \times 26.5 \mathrm{~m}$ plots $(\approx 0.05 \mathrm{ha})$. Treatments were applied over $2 \mathrm{yr}(1990$ and 1993) at both sites. Plant yield data were collected near the end of each growing season from 1990 through 2006. Standing crop estimates were made in 10 $31.5 \times 61 \mathrm{~cm}$ permanently staked sample subplots placed along two transects within each plot. Ocular estimates of in-field plant weight in grams were made within each subplot separately for grass, snakeweed, and forbs. To verify yield estimates and to determine plant moisture content, clipped samples were periodically randomly taken next to the permanent subplot, weighed in the field, and compared after oven drying to $60^{\circ} \mathrm{C}$. A summary report (McDaniel et al. 2010) provides additional and updated detail about sampling procedures, plant cover, and species composition for all treatments. For this study, only end-of-season standing crop measurements taken in untreated experimental plots were used.

Figure 1 summarizes grass and snakeweed yields reported on control areas by McDaniel et al. (2010). Snakeweed yield on untreated areas averaged about $440 \mathrm{~kg} \cdot \mathrm{ha}^{-1}$ from 1990 through 1993 but it declined by over $50 \%$ by 1994 . There was only minor recruitment of new plants in the years that followed, and snakeweed yield on untreated areas remained $<300 \mathrm{~kg} \cdot \mathrm{ha}^{-1}$ for the remainder of the study. Grass yield in untreated areas was not different $(P<0.05)$ among the two study sites. Over all years, grass yield averaged $594 \mathrm{~kg} \cdot \mathrm{ha}^{-1}$. From 1990 through 1995, grass yield was below average at about $400 \mathrm{~kg} \cdot \mathrm{ha}^{-1}$. From 1996 through 1999, when growing season precipitation was near or above the long-term normal, grass yield in untreated areas increased and averaged about $900 \mathrm{~kg} \cdot \mathrm{ha}^{-1}$. Under drought conditions from late 1999 through 2003, grass yield fell sharply and averaged about
$275 \mathrm{~kg} \cdot \mathrm{ha}^{-1}$. From 2004 through 2006, rainfall was again favorable, and grass yield on untreated areas increased to about $900 \mathrm{~kg} \cdot \mathrm{ha}^{-1}$.

\section{Meteorological and Soil Moisture Data}

Weather stations supported with CR-10 multiport data loggers (Campbell Scientific Instruments, Inc, Logan, UT) were installed at both study sites in 1990 and recorded data at 5min intervals with data averaged hourly. Data recorded included precipitation, air temperature, soil temperature at $10 \mathrm{~cm}$ and $50 \mathrm{~cm}$ beneath the soil surface, wind speed and direction, and relative humidity. All data recorded by the weather stations are summarized by Torell et al. (2008). ${ }^{1}$

Long-term (1914-2006) average annual precipitation on the CRLRC was $370 \mathrm{~mm} \pm 12$ standard error of the mean (SEM; Torell et al. 2008, table 1). Precipitation during the April-October growing season averaged $283 \mathrm{~mm} \pm 10$ SEM. Averaged across the $17-y r$ study period, growing season rainfall and annual total rainfall were $95 \%$ and $88 \%$ of the long-term average, respectively.

Over the study period, patterns of precipitation were similar across years. Rain or snow events occurred on about $66 \mathrm{~d}$ of the year with $70 \%$ of precipitation days receiving less than $5 \mathrm{~mm}$. Days with precipitation exceeding $10 \mathrm{~mm}$ occurred about $15 \%$ of the time. The small storms were inconsequential for raising soil moisture levels, but Sala and Lauenroth (1982) found blue grama to effectively utilize these small storms, and this may contribute to its persistence as a dominant forage species on the central and southern Great Plains.

Growing season precipitation was substantially below average in 1990, 1993, 1995, 2000, 2001, 2003, and 2005 (Fig. 2). Drought conditions were pronounced from late 1999 through 2003, when growing season precipitation was from $92 \%$ to $45 \%$ of average.

Over the study period, average daily maximum air temperature at the study sites was $8.5^{\circ} \mathrm{C} \pm 0.12$ SEM during December-January and $29.3^{\circ} \mathrm{C} \pm 0.10$ SEM in July. Average daily minimum air temperature was $-4.4^{\circ} \mathrm{C} \pm 0.11$ SEM during December-January and $14.4^{\circ} \mathrm{C} \pm 0.07$ SEM in July. The interval between killing frosts averaged $186 \mathrm{~d}$.

An average daily minimum air temperature of about $10^{\circ} \mathrm{C}$ is needed for blue grama growth (Stubbendieck and Burzlaff 1970), and a composite temperature variable was computed from recorded hourly temperatures to capture the potential influence of temperature on grass growth. As summarized by Torell et al. (2008, fig. 7), on the CRLRC, average diurnal air temperatures begin to consistently exceed $10^{\circ} \mathrm{C}$ in early April and remain above this threshold until late October; thus, the estimated potential growing season for blue grama and other warm-season grasses on the CRLRC is about $214 \mathrm{~d}$. The temperature variable $\left(\mathrm{DEGREE}_{\mathrm{t}}\right.$ ) was computed by subtracting $10^{\circ} \mathrm{C}$ from the average daily diurnal temperature $(0600$ hours to 1800 hours) and summing this difference for the defined 214-d April-October potential growing season. The average number of degree days over the study period on both study sites was $2308 \pm 27$ SEM (Table 1). The years 2000, 2001, and 2003 were relatively hot with degree day values that were 1 standard deviation or more above average and with rainfall

${ }^{1}$ The South House (SH) and Oil Well (OW) sites referred to in the research report are referred to as site 1 and site 2, respectively, in this study. 
Table 1. Degree days and number of days during the growing season when simulated and probe-recorded soil moisture reached alternative levels, averaged across study sites.

\begin{tabular}{|c|c|c|c|c|c|c|c|}
\hline \multirow[b]{2}{*}{ Year } & \multirow[b]{2}{*}{ Degree days ${ }^{1}$} & \multicolumn{3}{|c|}{ Simulated $10 \mathrm{~cm}$} & \multicolumn{3}{|c|}{ Simulated $10-30 \mathrm{~cm}$} \\
\hline & & $\mathrm{LT}_{2} \mathrm{O}^{2}$ & GT20-30 & GT30 & LT20 & GT20-30 & GT30 \\
\hline 1990 & 2226 & & & $10^{3}$ & & & $10^{3}$ \\
\hline 1991 & 2059 & 74 & 84 & 57 & 79 & 90 & 46 \\
\hline 1992 & 2280 & 82 & 101 & 31 & 86 & 105 & 23 \\
\hline 1993 & 2220 & 104 & 99 & 12 & 111 & 94 & 9 \\
\hline 1994 & 2374 & 53 & 111 & 51 & 62 & 116 & 37 \\
\hline 1995 & 2259 & 83 & 98 & 33 & 91 & 103 & 20 \\
\hline 1996 & 2225 & 74 & 54 & 87 & 74 & 71 & 69 \\
\hline 1997 & 1986 & 39 & 107 & 69 & 38 & 119 & 58 \\
\hline 1998 & 2368 & 70 & 103 & 41 & 71 & 110 & 33 \\
\hline 1999 & 2164 & 76 & 115 & 23 & 82 & 117 & 15 \\
\hline 2000 & 2488 & 171 & 29 & 14 & 173 & 29 & 13 \\
\hline 2001 & 2542 & 84 & 114 & 17 & 94 & 110 & 10 \\
\hline 2002 & 2361 & 88 & 87 & 40 & 98 & 86 & 31 \\
\hline 2003 & 2533 & 132 & 82 & 0 & 138 & 77 & 0 \\
\hline 2004 & 2238 & 54 & 89 & 72 & 55 & 105 & 55 \\
\hline 2005 & 2416 & 81 & 87 & 46 & 70 & 105 & 40 \\
\hline 2006 & 2387 & 102 & 46 & 67 & 103 & 49 & 63 \\
\hline Average & 2308 & 85 & 88 & 41 & 89 & 93 & 32 \\
\hline \multirow[t]{2}{*}{ SEM } & 27 & 8 & 6 & 6 & 8 & 6 & 5 \\
\hline & & \multicolumn{3}{|c|}{ Probe-recorded,10 cm } & \multicolumn{3}{|c|}{ Probe-recorded, $10-30 \mathrm{~cm}$} \\
\hline 2001 & & 110 & 87 & 17 & 96 & 109 & 10 \\
\hline 2002 & & 133 & 50 & 32 & 43 & 129 & 42 \\
\hline 2003 & & 151 & 52 & 11 & 83 & 108 & 24 \\
\hline 2004 & & 105 & 53 & 57 & 27 & 104 & 84 \\
\hline 2005 & & 97 & 54 & 63 & 45 & 88 & 82 \\
\hline 2006 & & 107 & 28 & 80 & 96 & 23 & 96 \\
\hline Average & & 117 & 54 & 43 & 65 & 93 & 56 \\
\hline SEM & & 8 & 8 & 11 & 12 & 15 & 15 \\
\hline
\end{tabular}

${ }^{1}$ Additional detail by site provided by Torell et al. $(2008$, table 8$)$.

${ }^{2} \mathrm{LT20}$ indicates no. of days in the 214-d growing season with midnight soil moisture $(\mathrm{SM})<20 \%$; GT20-30, no. of days with $20 \% \leq \mathrm{SM}<30 \%$; and $\mathrm{GT} 30$, no. of days with SM $\geq 30 \%$. ${ }^{3}$ Estimated from other years with similar levels of third-quarter rainfall. This estimate was needed for lagged variables in the regression models.

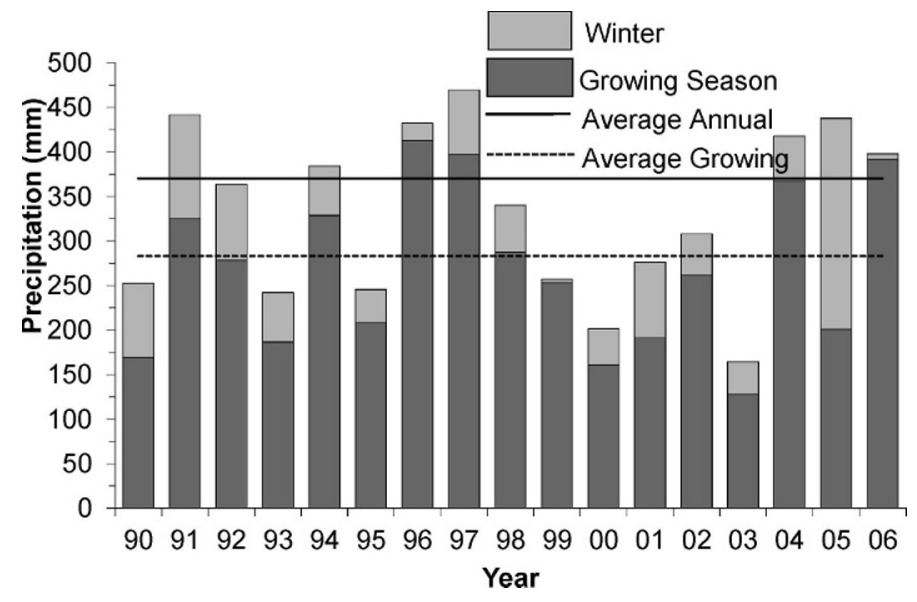

Figure 2. Average annual, winter, and growing season rainfall $(\mathrm{mm})$ recorded at the two study sites (1990-2006) as compared to long-term averages (1914-2006). Winter rainfall totals include November-March, growing season rainfall includes April-October, and annual is the total bar height. totals that were well below average. The years 1991, 1993, 1997, and 1999 were relatively cool years, with below-average degree day measurements.

In 2001, TDR soil moisture probes (CS 615-L; Campbell Scientific Instruments, Inc) were installed at each weather station to continuously monitor volumetric soil water. Two TDR probes were buried in the same configuration at each site. When we buried the probes it was not known how to best position them in the soil profile. After consulting with a soil scientist with experience with TDR probes, it was decided to place one horizontally in the soil profile at a $10-\mathrm{cm}$ depth, which is the approximate blue grama root depth. The second probe was positioned vertically at a $10-\mathrm{cm}$ to $30-\mathrm{cm}$ depth.

After a 5-yr calibration period, it was determined that soil moisture probes were scaled differently between the two sites. At the $10-\mathrm{cm}$ depth, the site 2 probe consistently recorded about $20 \%$ higher than the site 1 probe. At the $10-\mathrm{cm}$ to $30-\mathrm{cm}$ depth, the site 1 probe consistently recorded about $6 \%$ higher than the site 2 probe. Thus, to calibrate, on two different dates in 2006, four field soil moisture samples were taken by coring 
to the moisture probe recording depths and weighing soil samples before and after oven drying to $60^{\circ} \mathrm{C}$. Based on the calibration, site 2 readings were multiplied by 0.80 at the 10 $\mathrm{cm}$ depth and by 1.06 at the $10-\mathrm{cm}$ to $30-\mathrm{cm}$ depth. With these adjustments, the volumetric water content readings from the sites were similar, from about $15 \%$ for very dry soils to about $55 \%$ with saturated soils. The adjusted readings were near the $7 \%$ to $51 \%$ range estimated at the study sites at a $10-\mathrm{cm}$ depth by Berry (1992) using pressure plate tests.

\section{Simulated Soil Moisture}

An estimate of volumetric water content over the 1991-2006 period, which includes years prior to TDR probe installation, was made for each site using a modified Sacramento Soil Moisture Accounting Model (Sacramento Soil Moisture Accounting Model with Heat Transfer, SAC-HT). As described by Koren et al. (2006), the SAC-HT model uses climatological estimates of water evaporation from the National Weather Service Atlas (Farnsworth et al. 1982) and data defining hourly rainfall and temperatures realized at a particular site to simulate soil moisture conditions. Surface runoff and infiltration to different soil layers are estimated. The SAC-HT model has 11 major and five minor parameters, in part derived from soil and vegetation data (Koren et al. 2003). Parameter grids with spatial resolution from $1 \mathrm{~km}$ to $4 \mathrm{~km}$ are available over the conterminous United States. Model parameters for the study sites were derived from these $1-\mathrm{km}$ grids. Default regional values were assigned for minor parameters. A description of the original Sacramento Soil Moisture Accounting Model (SAC-SMA) and various modifications for the SAC-HT model can be found in Burnash (1995) and Koren et al. (1999, 2003, 2006).

Time series plots of simulated and probe-recorded values and difference statistics were used to evaluate the accuracy of soil moisture simulations. Statistics computed included mean and variance of predicted and observed values, mean bias error (MBE), root mean square error (RMSE), the correlation coefficient, and an index of agreement $(d)$. The MBE shows the magnitude of the average over- or underprediction of the model, and the RMSE shows the average deviation between predicted and observed values regardless of sign. Zero and 1 bound the $d$ statistic, with a 1 indicating complete agreement between the predicted and observed values. A more detailed description of these comparative statistics is provided by Andales et al. (2006).

For use in the regression analysis, soil moisture readings recorded or simulated at midnight for a particular site and soil depth were grouped into three categories: low, with readings less than $20 \%$ by volume (LT20); intermediate, with readings between $20 \%$ and 30\% (GT20-30); and high, with readings greater than $30 \%$ (GT30). Because the simulation model requires a warmup period for initialization, valid simulated values were considered to start in January 1991.

\section{Rainfall and Soil Moisture Modeling}

Potential explanatory variables in regression equations included alternative annual measures of realized moisture conditions, along with other variables measuring soil and air temperature. Ordinary least squares regression equations were developed and compared for a model that included traditional variables measuring accumulated seasonal rainfall totals with other models that used soil moisture to characterize moisture conditions. Quadratic and cubic specifications were considered for the degree day variable $\left(\mathrm{DEGREE}_{\mathrm{t}}\right)$ with anticipation that temperature increases would first be advantageous to grass production but that a point would eventually be reached beyond which further temperature increases diminished yields.

In each of the models, SAS ${ }^{\mathrm{TM}}$ software diagnostics did not indicate a serious problem with multicollinearity, but an unequal variance (heteroscedasticity) across years was problematic based on the White test $(P<0.001)$. Thus, White's heteroscedasticity consistent estimator of the variance-covariance matrix was used for hypothesis testing.

Broom snakeweed has been shown to retard grass growth, and the amount of snakeweed $\left(\mathrm{kg} \cdot \mathrm{ha}^{-1}\right)$ present was included in the models in natural $\log$ form $\left(\right.$ LNGUSA $\left._{\mathrm{t}}\right)$. A minimum of $1 \mathrm{~kg} \cdot \mathrm{ha}^{-1}$ of snakeweed was assumed to be present on each experimental plot so as to avoid errors that occur when taking logs of zero amounts. With the log specification, broom snakeweed is defined to suppress grass yield at a decreasing rate, similar to the overstory/understory curves defined for numerous brush species including broom snakeweed (McDaniel et al. 1993).

Across the $17 \mathrm{yr}$, a total of 186 estimates of plant yield were made on the 12 control plots established at the two study sites. Estimates of simulated soil moisture were not available until 1991 , so 1990 data were excluded from the regression analysis. Though annual estimates of rainfall, soil moisture, and temperature were the same at a particular site, variation in snakeweed production between plots provided additional information to further explain variation in grass yields; thus data were aggregated to the plot level. The sample size for the regression analysis was 180 observations using 1991-2006 data. Various functional forms and combinations of monthly rainfall amounts and soil moisture levels were initially considered when estimating the regression equations. These initial model formulations are described next.

Rainfall. Snakeweed yield, degree days, and seasonal rainfall amounts were the explanatory variables used in the final rainfall model. In initial models, a site dummy variable (SITEDUM, site $1=0$, site $2=1$ ) was not statistically significant $(P=0.88)$ indicating no difference by site, so data were combined across sites for the rainfall model. We initially considered rainfall amounts during the fourth quarter (Q4) of the previous year and first-quarter (Q1) to third-quarter (Q3) rainfall amounts during the current year as separate explanatory variables. Parameter estimates for $\mathrm{Q} 4_{\mathrm{t}-1}$ and $\mathrm{Q} 1_{\mathrm{t}}$ were not statistically different in restricted least squares regression models $(P=0.30)$, and thus were combined in the final model. An additional lagged Q3 rainfall variable was also evaluated along with the interaction term $\mathrm{Q} 3 \mathrm{t} \times \mathrm{Q} 3_{\mathrm{t}-1}$.

The final rainfall regression model selected, based on statistical significance of variables and previous research findings is given by the following equation:

$$
\begin{aligned}
\mathrm{Y}_{\mathrm{t}}= & \alpha_{0}+\alpha_{1}\left(\mathrm{Q} 4_{\mathrm{t}-1}+\mathrm{Q} 1_{\mathrm{t}}\right)+\alpha_{2} \mathrm{Q} 2_{\mathrm{t}}+\alpha_{3} \mathrm{Q} 3_{\mathrm{t}}+\alpha_{4} \mathrm{Q} 3_{\mathrm{t}-1} \times \mathrm{Q} 3_{t} \\
& +\alpha_{5} \mathrm{LNGUSA}_{\mathrm{t}}+\alpha_{6} \mathrm{DEGREE}_{\mathrm{t}}+\alpha_{7} \mathrm{DEGREE}_{\mathrm{t}}^{2}+\varepsilon
\end{aligned}
$$

Soil Moisture. Relating standing crop yield to soil moisture levels would not have been possible without using simulated 
soil moisture data. Soil moisture probes were not installed until fall 2001, and attempts to estimate grass yield using data for only the most recent $5 \mathrm{yr}$ were not successful. Eleven of the $17 \mathrm{yr}$ with grass yield data had a recorded daily rainfall and temperature history but no recorded soil moisture. Four different soil moisture regression models are presented depending on soil moisture recording depth and type of soil moisture data used (simulated only or probe recorded when available). Additional combinations of soil moisture variables were also examined to explore how interyear soil moisture conditions influenced grass production. For each soil moisture measurement depth, the following regression model was defined:

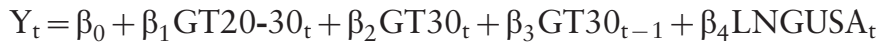

$$
\begin{aligned}
& +\beta_{5} \text { SITEDUM }_{+} \beta_{6} \text { DEGREE }_{\mathrm{t}}+\beta_{7} \text { DEGREE }_{\mathrm{t}}^{2} \\
& +\beta_{8} \text { DEGREE }_{\mathrm{t}}^{3}+\varepsilon \text {. }
\end{aligned}
$$

Days with soil moisture below $20 \%$ were excluded from the regression equation, thus $\hat{\beta}_{1}$ and $\hat{\beta}_{2}$ provide estimates of the daily yield increase for wetter conditions relative to the driest condition. Unlike the rainfall regression, the site dummy variable was significant and included in the model. Also different was the significance of the variable measuring the number of days with high soil moisture during the previous year $\left(\mathrm{GT}_{30} \mathrm{t}_{\mathrm{t}-1}\right)$, but the interaction term GT30 $\mathrm{t}_{-1} \times \mathrm{GT} 3 \mathrm{t}_{\mathrm{t}}$ was not significant $(P>0.25)$ and thus was excluded. Other lagged soil moisture variables were also initially considered, but they were not statistically significant and thus were excluded.

\section{RESULTS}

\section{Simulated Soil Moisture}

As shown in Figure 3, both recorded and simulated soil moisture followed a similar annual trend. The seasonal pattern of wet-up during the spring and summer months with moisture rejuvenation following storms was evident, as was the drydown pattern of late summer and fall. During drought years and during late fall and winter months, soil moisture generally remained less than $20 \%$ by volume.

Recorded vs. simulated estimates of soil moisture from 2001 to 2006 were similar across study sites. After calibration, simulated values agreed well with probe-recorded measurements. The mean value of probe-recorded soil moisture measured across both sites was 22.9 \pm 0.16 SEM at the 10$\mathrm{cm}$ depth and $27.7 \pm 0.17$ SEM at the $10-\mathrm{cm}$ to $30-\mathrm{cm}$ depth. The similar averages for the simulated series were $25.1 \pm 0.12$ SEM and $24.5 \pm 0.11$ SEM, respectively.

For both probe depths the MBE was near zero (0.0007). The estimated correlation coefficient for recorded vs. simulated values at the $10-\mathrm{cm}$ depth was 0.84 , the $d$ statistic was 0.87 , and the RMSE was 0.09 , indicating strong agreement between recorded and simulated values. The similar measures at the $10-\mathrm{cm}$ to $30-\mathrm{cm}$ depth were $0.75,0.77$, and 0.13 , respectively.

The range and variance in simulated soil moisture was less than the recorded probe data at the deeper depth, and simulated values were much less extreme immediately following significant rainfall events (Fig. 3). The reduced correlation and reduced range in simulated values at the $10-\mathrm{cm}$ to $30-\mathrm{cm}$ depth, as compared to probe-recorded values, is perhaps explained by the vertical configuration of the probes at this depth. Although similar on average and with unbiased estimates, simulated soil moisture tended to undercategorize the number of days in the driest state as compared to the proberecorded values. Over the comparable 2001-2006 period, more days were categorized in the intermediate category with simulated data (Table 1).

\section{Rainfall Regression}

Table 2 shows the results of the rainfall regression (Equation 1). The number of degree days accumulated over the growing season $\left(\right.$ DEGREE $\left._{t}\right)$ fit the data best as a quadratic function. Over the approximate temperature range $(1900<$ DEGREE $\left._{t}<2600\right)$, the quadratic function suggests higher temperatures can be both beneficial and detrimental to grass growth. Starting at the observed minimum degree days, regression results suggest estimated standing crop increased until slightly below the mean of degree days and then rapidly decreased. As an example, when the function is evaluated at mean levels for the explanatory variables (Table 2), estimated standing crop would be $489 \mathrm{~kg} \cdot \mathrm{ha}^{-1}$ if degree days were 2000 , peaking at $695 \mathrm{~kg} \cdot \mathrm{ha}^{-1}$ at 2239 degree days, and decreasing to only $348 \mathrm{~kg} \cdot \mathrm{ha}^{-1}$ when degree days increase to 2550 . The optimal daily diurnal temperature for maximum grass production would be near the daily averages reported for the CRLRC by Torell et al. (2008, fig. 7 ) so that accumulated degree days over the growing season would be from about 2100 to 2300 . Numerous days with temperatures hotter than average meant degree days reached the 2400 to 2500 range, which significantly reduced grass yield. Annual standing crop was influenced by both temperature and moisture conditions.

The -24.43 parameter estimate for $\alpha_{5}$ (Equation 1), given the linear-log specification for the snakeweed variable, indicates that a $1 \%$ increase in snakeweed yield decreased grass yield by about $0.24 \mathrm{~kg} \cdot \mathrm{ha}^{-1}$. Grass yield diminished at a decreasing rate with increasing snakeweed, similar to the findings of McDaniel et al. (1993).

Contrary to the results obtained here, others have found winter rainfall $\left(\mathrm{Q} 4_{t-1}\right.$ and $\left.\mathrm{Q} 1_{\mathrm{t}}\right)$ to be an insignificant factor in determining herbaceous production on Southwestern rangelands (Pieper et al. 1971; Cable 1975; McDaniel et al. 1993). Our regression parameter estimates indicate $1 \mathrm{~mm}$ of winter rainfall adds $1.86 \mathrm{~kg} \cdot \mathrm{ha}^{-1}$ to herbaceous production, as compared to $0.19 \mathrm{~kg} \cdot \mathrm{ha}^{-1}$ if the rainfall event occurs during Q2. Added grass yield during Q3 is confounded because it also depends on rainfall conditions during $\mathrm{Q} 3$ of the previous year. Similar to the findings of Cable (1975), the interaction term between Q3 rainfall between years was a significant variable, but the lagged $\mathrm{Q} 3_{\mathrm{t}-1}$ rainfall variable was not. If, as an example, $\mathrm{Q} 3_{\mathrm{t}-1}$ was at the 162.6- $\mathrm{mm}$ average, the marginal impact of an additional millimeter of rainfall during the current Q3 time period would be $2.08 \mathrm{~kg} \cdot \mathrm{ha}^{-1}\left(\hat{\alpha}_{3}+\hat{\alpha}_{4} \times 162.6 \mathrm{~mm} \times 1 \mathrm{~mm}=2.08\right)$. It was not expected that the estimated winter parameter would be as high as it was relative to the estimates for the other quarters, especially Q3.

The $R^{2}$ of the rainfall model was estimated to be $49 \%$, which is less than the approximate $70 \%$ value reported for similar 

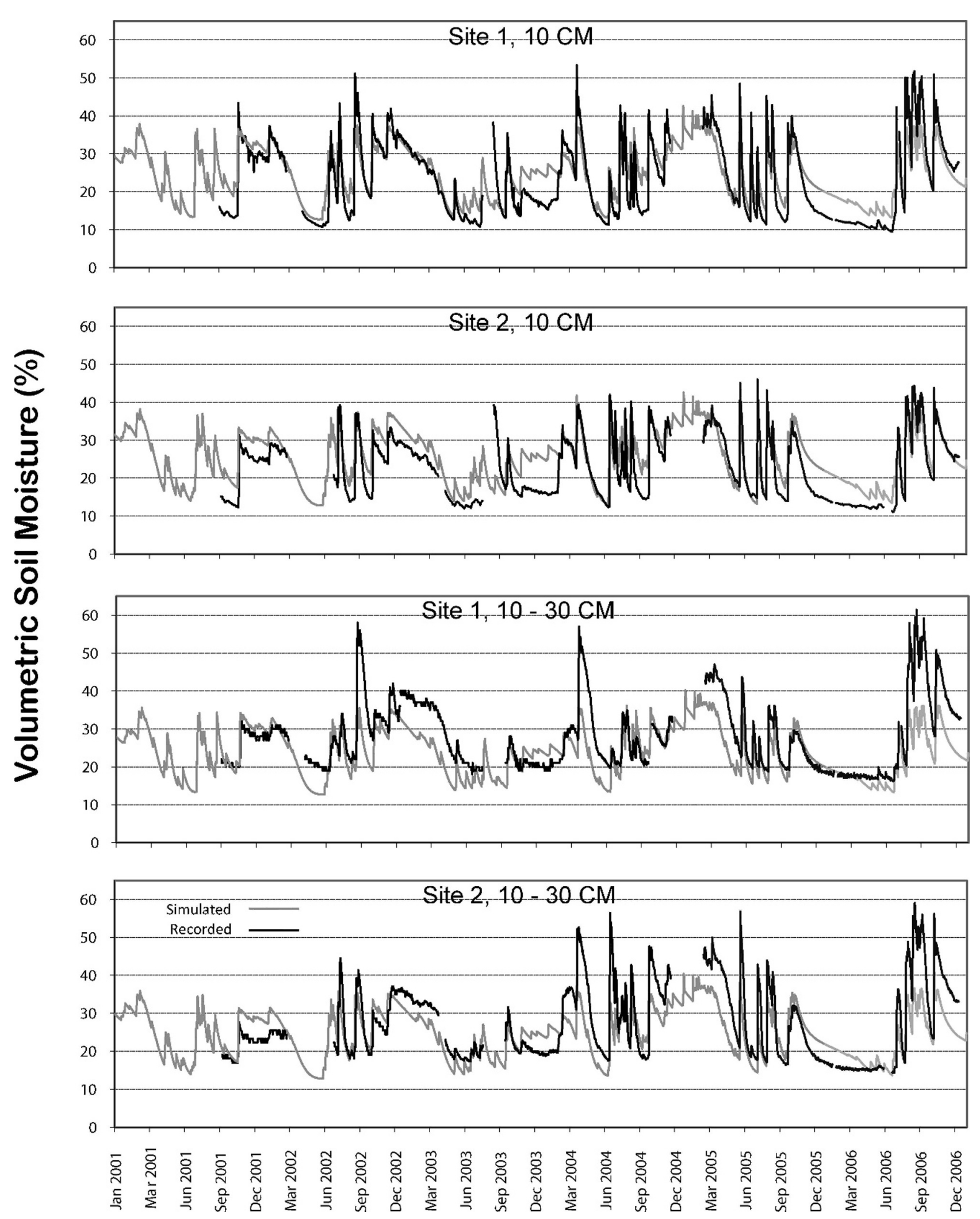

Figure 3. Recorded (black) and simulated (gray) volumetric soil moisture (\%) measured each day at midnight at the 10-cm and the 10-cm to 30-cm depth, by site, 2001-2006.

multiple regression models by Pieper et al. (1971), Cable (1975), and Khumalo and Holechek (2005). Residual plots indicated the model tended to underpredict grass yield at site 2 during 2004, 2005, and 2006, but this was not the case at site
1. The relatively low explanatory power of the model and the apparent underprediction of standing crop during drought periods likely occurred because measurements of standing crop included residual growth from previous years and thus some of 
Table 2. Regression parameter estimates for estimating grass yield as a function of degree days, seasonal rainfall totals, and level of snakeweed infestation.

\begin{tabular}{|c|c|c|c|c|c|c|}
\hline Parameter & Variable & Mean \pm SEM & Variable description & Parameter estimate & $\begin{array}{c}\text { Consistent standard } \\
\text { error }\end{array}$ & $t$-value $^{1}$ \\
\hline$\alpha_{0}$ & Intercept & & Model intercept & -17801 & 3794 & $-4.69^{\star * *}$ \\
\hline$\alpha_{1}$ & $Q 4_{t-1}+Q 1_{t}$ & $90.5 \pm 3.7$ & $\begin{array}{l}\text { Amount of rainfall }(\mathrm{mm}) \\
\text { received during quarter } 4 \text { of } \\
\text { previous year or quarter } 1 \text { of } \\
\text { the current year }\end{array}$ & 1.86 & 0.321 & $5.78^{\star * *}$ \\
\hline$\alpha_{2}$ & $\mathrm{Q} 2_{\mathrm{t}}$ & $76.2 \pm 3.7$ & $\begin{array}{l}\text { Amount of rainfall }(\mathrm{mm}) \\
\text { received during quarter } 2\end{array}$ & 0.19 & 0.460 & 0.41 \\
\hline$\alpha_{3}$ & $Q 3_{t}$ & $162.6 \pm 5.8$ & $\begin{array}{l}\text { Amount of rainfall }(\mathrm{mm}) \\
\text { received during quarter } 3\end{array}$ & 0.863 & 0.383 & $2.25^{\star *}$ \\
\hline$\alpha_{4}$ & $\mathrm{Q} 3_{\mathrm{t}-1} \times \mathrm{Q} 3_{\mathrm{t}}$ & $24089 \pm 1252$ & Quarter 3 rainfall interaction & 0.0075 & 0.0023 & $3.23^{* * *}$ \\
\hline$\alpha_{5}$ & LNGUSA $_{t}$ & $2.55 \pm 0.196$ & $\begin{array}{l}\text { Natural log of broom } \\
\text { snakeweed weight }\left(\mathrm{kg} \cdot \mathrm{ha}^{-1}\right)\end{array}$ & -24.43 & 7.039 & $-3.47^{\star \star \star}$ \\
\hline$\alpha_{6}$ & DEGREE $_{t}$ & $2308 \pm 27$ & $\begin{array}{l}\text { Accumulated degree days above } \\
10^{\circ} \mathrm{C} \text { over the growing season }\end{array}$ & 16.12 & 3.258 & $4.95^{\star * *}$ \\
\hline$\alpha_{7}$ & DEGREE $_{t}^{2}$ & & Degree days squared & -0.0036 & 0.0007 & $-5.15^{\star \star \star}$ \\
\hline$R^{2}$ & & & & & 0.485 & \\
\hline Adjusted $R^{2}$ & & & & & 0.464 & \\
\hline$n$ & & & & \multicolumn{3}{|c|}{180} \\
\hline \multicolumn{4}{|c|}{ Mean of dependent variable (grass yield, $\mathrm{kg} \cdot \mathrm{ha}^{-1}$ ) } & \multicolumn{3}{|c|}{601} \\
\hline \multicolumn{4}{|c|}{ Root mean square error } & & 260 & \\
\hline
\end{tabular}

${ }^{1}$ Double and triple asterisks denote coefficients were statistically significant at the $5 \%$ and $1 \%$ levels, respectively.

the measured herbaceous production had not actually been produced that year.

\section{Soil Moisture Regressions}

Regression results were consistent between the $10-\mathrm{cm}$ and the $10-\mathrm{cm}$ to $30-\mathrm{cm}$ soil moisture probes. Results were also similar at the $10-\mathrm{cm}$ depth when actual probe data were used when available vs. regressions that only used simulated soil moisture (Table 3). Comparing the rainfall model (Table 2) to the various soil moisture models shows a marked improvement in explanatory power when using soil moisture to define moisture conditions. The adjusted $R^{2}$ improved by over $12 \%$, and it did not matter whether simulated or probe-recorded soil moisture data were used to categorize moisture conditions. In fact, the soil moisture model that used simulated values at the $10-\mathrm{cm}$ to $30-\mathrm{cm}$ depth had the highest adjusted $R^{2}(65.4 \%$; Table 3$)$. Residual plots also indicated an improved prediction of grass yield using soil moisture, especially during drought years.

Air temperature, as measured by degree days, was significant in three of the four soil moisture models (Table 3). For the soil moisture regressions, this variable fit best as a cubic function. As with the rainfall model, peak grass yield occurred when temperatures were near average, such that about 2200 degree days accumulate over the growing season.

The standing crop of grass, as expected, was found to depend largely on the number of days during the growing season when soil moisture conditions were relatively wet. Consider the regression using simulated data at the $10-\mathrm{cm}$ to $30-\mathrm{cm}$ depth. Each day during the growing season with a midnight soil moisture reading of between $20 \%$ and $30 \%$ increased grass yield by $1.82 \mathrm{~kg} \cdot \mathrm{ha}^{-1}$ relative to the yield obtained if the day were categorized in the driest state. Days with soil moisture exceeding $30 \%$ added $7.93 \mathrm{~kg} \cdot \mathrm{ha}^{-1}$ of grass yield, which was statistically more than the intermediate category $(P<0.0001)$. This suggests that days with movement of soil moisture to levels above $30 \%$ meant over four times the daily production of grass. The estimated peak grass yield obtainable would be about $1900 \mathrm{~kg} \cdot \mathrm{ha}^{-1}$, and that would occur on snakeweed-free areas with all days during the growing season having soil moisture above $30 \%$ and with realized diurnal daily temperatures near average levels.

The number of wet days during the previous year $\left(\mathrm{GT}^{2} \mathrm{O}_{\mathrm{t}-1}\right)$ was found to be an important variable for explaining herbaceous production during the current year. In fact, the GT30 $0_{-1}$ variable was an extremely important variable in the regression equations. The $R^{2}$ value increased over $20 \%$ with inclusion of this lagged variable. Similarly, Cable (1975) found the interaction variable between years explained nearly as much of the variability in year-to-year production as did multiple regressions with only current-period rainfall amounts included. As noted by Cable (1975), the lagged variable likely captures the improved plant health and production potential that exists when favorable plant growth conditions existed in the previous year.

\section{DISCUSSION}

Soil moisture is conceptually a better measure of water availability for predicting plant production because it considers accumulated, recent, and past history of rainfall events. We anticipated that using accumulated days when soil moisture levels were at low, intermediate, and high levels would improve standing crop estimates relative to using seasonal rainfall 
Table 3. Regression parameter estimates for estimating grass yield as a function of degree days, soil moisture levels, level of snakeweed infestation, and study site.

\begin{tabular}{|c|c|c|c|c|c|c|c|c|}
\hline \multirow[b]{2}{*}{ Parameter } & \multirow[b]{2}{*}{ Variable } & \multirow[b]{2}{*}{$\begin{array}{c}\text { Variable } \\
\text { description }\end{array}$} & \multicolumn{3}{|c|}{ 10-cm soil moisture measurement } & \multicolumn{3}{|c|}{ 10-30-cm soil moisture measurement } \\
\hline & & & $\begin{array}{l}\text { Parameter } \\
\text { estimate }\end{array}$ & $\begin{array}{c}\text { Consistent } \\
\text { standard error }\end{array}$ & $t$-value & $\begin{array}{l}\text { Parameter } \\
\text { estimate }\end{array}$ & $\begin{array}{c}\text { Consistent } \\
\text { standard error }\end{array}$ & $t$-value ${ }^{1}$ \\
\hline \multicolumn{9}{|c|}{ Simulated soil moisture only } \\
\hline$\beta_{0}$ & Intercept & Model intercept & -212890 & 59097 & $-3.60^{\star \star *}$ & -197932 & 56557 & $-3.50^{* * *}$ \\
\hline$\beta_{1}$ & GT20-30t & $\begin{array}{l}\text { Number of days with soil } \\
\text { moisture }>20 \% \text { and } \\
\leq 30 \%\end{array}$ & 1.36 & 0.600 & $2.27^{\star *}$ & 1.82 & 0.567 & $3.21^{* * *}$ \\
\hline$\beta_{2}$ & GT30t & $\begin{array}{c}\text { Number of days with soil } \\
\text { moisture }>30 \% \text { at } t\end{array}$ & 6.86 & 0.671 & $10.22^{* * *}$ & 7.93 & 0.782 & $10.14^{\star * *}$ \\
\hline$\beta_{3}$ & $\mathrm{GT} 30_{\mathrm{t}-1}$ & $\begin{array}{l}\text { Number of days with soil } \\
\text { moisture }>30 \% \text { at } t-1\end{array}$ & 8.36 & 0.791 & $10.57^{\star \star *}$ & 9.65 & 0.934 & $10.33^{* * *}$ \\
\hline$\beta_{4}$ & LNGUSA $_{t}$ & $\begin{array}{l}\text { Natural log of broom } \\
\text { snakeweed weight } \\
\left(\mathrm{kg} \cdot \mathrm{ha}^{-1}\right)\end{array}$ & -19.47 & 5.76 & $-3.38^{\star \star \star}$ & -18.17 & 5.46 & $-3.33^{\star * *}$ \\
\hline$\beta_{5}$ & SITEDUM & $\begin{array}{l}\text { Dummy variable for site } \\
\quad(\text { site } 1=0, \text { site } 2=1)\end{array}$ & -137.06 & 34.92 & $-3.93^{* \star *}$ & -176.91 & 32.85 & $-5.39 * * *$ \\
\hline$\beta_{6}$ & DEGREE & $\begin{array}{l}\text { Accumulated degree days } \\
\text { above } 10^{\circ} \mathrm{C} \text { over the } \\
\text { growing season }\end{array}$ & 273.92 & 78.17 & $3.50^{* * *}$ & 253.55 & 74.76 & $3.39^{* * *}$ \\
\hline$\beta_{7}$ & DEGREE $^{2}$ & Degree days squared & -0.117 & 0.034 & $-3.41^{* * *}$ & -0.108 & 0.033 & $-3.28^{* * *}$ \\
\hline$\beta_{8}$ & DEGREE $^{3}$ & Degree days cubed & 1.66E-05 & $5.02 \mathrm{E}-06$ & $3.31^{* * *}$ & $1.52 \mathrm{E}-05$ & 4.79E-06 & $3.18^{* * *}$ \\
\hline$R^{2}$ & & & 0.631 & & & 0.669 & & \\
\hline Adjusted & & & 0.614 & & & 0.654 & & \\
\hline Root mes & square erro & & 220 & & & 208 & & \\
\hline \multicolumn{9}{|c|}{ Actual probe-recorded data when available and simulated data otherwise } \\
\hline$\beta_{0}$ & Intercept & Model intercept & -184500 & 58999 & $-3.13^{\star * *}$ & -85432 & 59207 & -1.44 \\
\hline$\beta_{1}$ & GT20-30t & $\begin{array}{l}\text { Number of days with soil } \\
\text { moisture }>20 \% \text { and } \\
\leq 30 \%\end{array}$ & 0.99 & 0.651 & 1.52 & 1.09 & 0.432 & $2.52^{\star *}$ \\
\hline$\beta_{2}$ & $\mathrm{GT} 3 \mathrm{O}_{\mathrm{t}}$ & $\begin{array}{c}\text { Number of days with soil } \\
\text { moisture }>30 \% \text { at } t\end{array}$ & 5.22 & 0.664 & $7.85^{\star \star \star}$ & 3.40 & 0.711 & $4.78^{\star \star \star}$ \\
\hline$\beta_{3}$ & GT30t-1 & $\begin{array}{l}\text { Number of days with soil } \\
\text { moisture }>30 \% \text { at } t-1\end{array}$ & 7.49 & 0.835 & $8.97^{\star \star \star}$ & 6.87 & 0.781 & $8.79 * * *$ \\
\hline$\beta_{4}$ & LNGUSA $_{t}$ & $\begin{array}{l}\text { Natural log of broom } \\
\text { snakeweed weight } \\
\left(\mathrm{kg} \cdot \mathrm{ha}^{-1}\right)\end{array}$ & -19.75 & 6.73 & $-2.93^{\star \star \star}$ & -3.46 & 6.52 & -0.53 \\
\hline$\beta_{5}$ & SITEDUM & $\begin{array}{l}\text { Dummy variable for site } \\
\quad(\text { site } 1=0, \text { site } 2=1)\end{array}$ & -77.61 & 36.80 & $-2.11^{* *}$ & -72.45 & 33.17 & $-2.18^{* *}$ \\
\hline$\beta_{6}$ & DEGREE & $\begin{array}{l}\text { Accumulated degree days } \\
\text { above } 10^{\circ} \mathrm{C} \text { over the } \\
\text { growing season }\end{array}$ & 237.11 & 78.14 & $3.03^{\star * *}$ & 106.87 & 78.77 & 1.36 \\
\hline$\beta_{7}$ & DEGREE $^{2}$ & Degree days squared & -0.101 & 0.034 & $-2.94^{\star * *}$ & -0.044 & 0.035 & -1.26 \\
\hline$\beta_{8}$ & DEGREE $^{3}$ & Degree days cubed & $1.43 \mathrm{E}-05$ & $5.03 \mathrm{E}-06$ & $2.84^{\star * *}$ & $5.93 \mathrm{E}-06$ & $5.11 \mathrm{E}-06$ & 1.16 \\
\hline$R^{2}$ & & & 0.590 & & & 0.620 & & \\
\hline Adjusted & & & 0.571 & & & 0.602 & & \\
\hline Root mes & square erro & & 232 & & & 224 & & \\
\hline$n$ & & & 180 & & & 180 & & \\
\hline Mean of & pendent vari & le (standing crop, $\mathrm{kg} \cdot \mathrm{ha}^{-1}$ ) & 601 & & & 601 & & \\
\hline
\end{tabular}

${ }^{1}$ Double and triple asterisks denote coefficients were statistically significant at the $5 \%$ and $1 \%$ levels, respectively. 
amounts, and this was found to be the case. The adjusted $R^{2}$ increased from $14 \%$ to $19 \%$ using soil moisture variables in the regression equation instead of seasonal rainfall totals. There are tradeoffs, however, as obtaining probe-recorded soil moisture measurements requires additional effort to install and maintain recording devices, which incur periodic recording errors. Similarly, the use of simulated soil moisture requires additional modeling effort to map the realized or projected rainfall and temperature history to daily soil moisture conditions.

In this study, a high amount of grass yield variability between years remained unexplained with adjusted $R^{2}$ values of about $60 \%$ for the soil moisture regression models and $46 \%$ for the rainfall model. Measuring herbaceous standing crop, which included some residual production from earlier years, likely contributed to this variability, especially in low production years. Further, as suggested by Pieper et al. (1974), the lateseason data collection may not have captured peak production for the year. Another factor contributing to annual herbaceous production variation could have been the lack of livestock grazing at the study sites, but natural herbivory by insects, deer, rodents, and other animals did occur, and stagnant and decadent forage plants were not observed.

Soil moisture probes that we installed in 2001 on the CRLRC research sites provide some of the first long-term continuous measurements of soil moisture on rangelands. Yet, given the relatively large variation in annual grass production on arid western rangelands, many years of measurement will be required before the sample size is adequate to relate annual grass yield variation using only data from the onsite soil moisture probes. Periodic recording errors will always be a problem. Only by augmenting with simulated soil moisture for earlier years and periods with missing data could adequate regression equations explaining annual variation in grass yield using soil moisture be defined.

We used the number of days over the growing season when soil moisture reached low, intermediate, and high levels to explain annual variation in forage production. Alternative measurements may provide a better definition of moisture availability; perhaps conversion to accumulated soil water content or some conversion to potential evapotranspiration as used in sophisticated rangeland simulation models (Andales et al. 2006).

\section{Forecasting Forage Production}

Accurate forage projections start with an accurate forecast of what forthcoming temperature and moisture conditions will be, with adequate lead time for effective management adjustments. The Climate Prediction Center (CPC) of the National Weather Service provides short-term and long-term predictions of temperature and precipitation conditions (National Weather Service Climate Prediction Center [NWS-CPC] 2010). Recently, SAC-HT was included in the suite of NWS-CPC models, and multimodel ensemble-based probabilistic soil moisture prediction is available from the NWS-CPC Web site. These relatively short-term soil moisture projections are not currently of adequate duration to project growing season moisture conditions without significant extrapolation. The forecasts could be improved by refining and expanding the lead time and length of SAC-HT estimates for soil moisture, with further quantification of relationships between seasonal forage production and the forecasted values. Because wet days most influenced grass yield, the forage projection would be most accurate when the number of wet days could be projected with some degree of accuracy.

\section{IMPLICATIONS}

Early in the year, when stocking rate decisions are made, there is no way of knowing what kind of forage season is to follow. Wide yearly and seasonal differences in forage production can be expected depending largely on soil moisture and temperature conditions over the upcoming season. Understanding the relationship between environmental conditions and expected grass growth is important for improving stocking rate decisions. Measured or simulated soil moisture is conceptually a more useful measure than seasonal rainfall totals for predicting and explaining annual forage production differences. This research demonstrates that this is in fact the case. Although this research did not use projected temperature and precipitation to predict future herbaceous production, the study did find an improved estimate of realized forage conditions once temperature and soil moisture conditions were known. Simulated soil moisture data improved predictive grass yield estimates to a level equivalent to using onsite moisture probes to categorize daily moisture conditions. This research demonstrates that potential exists to better predict forage conditions based on forecast information using soil moisture data instead of the traditional input of seasonal rainfall totals.

\section{ACKNOWLEDGMENTS}

We thank former graduate students in the Department of Animal and Range Sciences and the Department of Agricultural Economics, New Mexico State University, who assisted with various aspects of this research, including Phil Berry, Charles Hart, Bret Carroll, Ballard Wood, Garrett Timmons, Suman Majumdar, and Christian Ebel. We also thank Shad Cox and other staff at the CRLRC for their assistance.

\section{LITERATURE CITED}

Andales, A. A., J. D. Derner, L. R. Ahuja, and R. H. Hart. 2006. Strategic and tactical prediction of forage production in northern mixed-grass prairie. Rangeland Ecology \& Management 59:576-584.

BerRY, P. N. 1992. Influence of soil moisture on propagation and survival of broom snakeweed, Gutierrezia sarothrae (Pursh) Britt. and Rusby [thesis]. Las Cruces, NM, USA: New Mexico State University. $84 \mathrm{p}$.

Bowman, K. J., D. W. Meister, D. B. Crezee, B. G. Bourlier, and R. E. Neher. 1970. Soil survey, Torrance Area, New Mexico. Washington, DC, USA: US Department of Agriculture. 149 p.

Briggs, J. M., AND A. K. Knapp. 1995. Interannual variability in primary production in tallgrass prairie: climate, soil moisture, topographic position, and fire as determinants of aboveground biomass. American Journal of Botany 82:1024-1030.

BURNASH, R. J. C. 1995. The NWS river forecast system—catchment modeling. In: V. P. Singh [ED.]. Computer models of watershed hydrology. Highlands Ranch, CO, USA: Water Resources Publications.

Cable, D. R. 1975. Influence of precipitation on perennial grass production in the semidesert southwest. Ecology 56:981-986.

DAHL, B. E. 1963. Soil moisture as a predictive index to forage yield for the Sandhills range type. Journal of Range Management 16:128-132. 
Farnsworth, R. K., E. S. Thompson, and E. L. Peck. 1982. Evaporation atlas for the contiguous 48 United States. Silver Spring, MD, USA: US Dept of Commerce, National Oceanic and Atmospheric Administration, National Weather Service Technical Report, NWS 33. 28 p.

Khumalo, G., and J. Holechek. 2005. Relationships between Chihuahuan Desert perennial grass production and precipitation. Rangeland Ecology \& Management 58:239-246.

Koren, V., F. Moreda, S. Reed, M. Smith, and Z. Zhang. 2006. Evaluation of gridbased distributed hydrological model over a large area. In: Predictions in ungauged basins: promise and progress. Proceedings of symposium S7, Seventh IAHS Scientific Assembly; 3-9 April 2005; Foz do Iguacu, Brazil. Foz do Iguacu, Brazil: International Association of Hydrological Sciences, IAHS Publication 303. p. 47-56.

Koren, V., J. Schaake, K. Mitchell, Q. Y. Duan, F. Chen, and J. M. Baker. 1999. A parameterization of snowpack and frozen ground intended for NCEP weather and climate models. Journal of Geophysical Research 104:1956919585

Koren, V., M. Smith, and Q. Duan. 2003. Use of a priori parameter estimates in the derivation of spatially consistent parameter sets of rainfall-runoff models. Washington, DC, USA: American Geophysical Union Report Number 1526758X, vol. 6. p. 239-254.

McDaniel, K. C., D. B. Carroll, and C. R. Hart. 2000. Broom snakeweed establishment following fire and herbicide treatments. Journal of Range Management 53:239-245.

McDaniel, K. C., C. A. Ebel, L. A. Torell, and D. M. Vanleeuwen. 2010. Single and repeated burning effects on blue grama range in Central New Mexico. Las Cruces, NM, USA: New Mexico State University Agricultural Experiment Station BL-800. 12 p.

McDaniel, K. C., C. R. Hart, and D. B. Carroll. 1997. Broom snakeweed control with fire on New Mexico blue grama rangeland. Journal of Range Management 50:652-659.

McDaniel, K. C., L. A. Torell, and J. W. Bain. 1993. Overstory-understory relationships for broom snakeweed-blue grama grasslands. Journal of Range Management 46:506-511.

Nelson, E. W. 1934. The influence of precipitation and grazing upon black grama grass range. Washington, DC, USA: US Dept of Agriculture Technical Bulletin no. 409. 32 p.
[NWS-CPC] National Weather Service Climate Prediction Center. 2010. Climate Prediction Center: outlook index. Available at: http://www.cpc.ncep.noaa.gov/ products/OUTLOOKS_index.shtml. Accessed 2 June 2010.

Pieper, R. D., C. H. Herbel, D. D. Dwyer, and R. E. Banner. 1974. Management implications of herbage weight changes on native rangeland. Journal of Soil and Water Conservation 29:227-229.

Pieper, R. D., J. R. Montoya, and V. L. Groce. 1971. Site characteristics on pinyonjuniper and blue grama ranges in south-central New Mexico. Las Cruces, NM, USA: New Mexico State University Agricultural Experiment Station Bulletin 573. $21 p$

RogleR, G. A., AND H. J. HAAs. 1947. Range production as related to soil moisture and precipitation on the northern Great Plains. Journal of the American Society of Agronomy 39:378-389.

Sala, O. E., and W. K. LauenRoth. 1982. Small rainfall events: an ecological role in semiarid regions. Oecologia 53:301-304.

Sala, O. E., W. J. Parton, L. A. Joyce, and W. K. Lauenroth. 1988. Primary production of the central grassland region of the United States. Ecology 69:40-45.

Smart, A. J., B. H. Dunn, P. S. Johnson, L. Xu, and R. N. Gatess. 2007. Using weather data to explain herbage yield on three Great Plains plant communities. Rangeland Ecology \& Management 60:146-153.

Sneva, F. A., And D. N. Hyder. 1962. Estimating herbage production on semiarid ranges in the Intermountain region. Journal of Range Management 15:88-93.

StubBendieck, J., and D. F. BuRzlafF. 1970. Effects of temperature and daylength on axillary bud and tiller development in blue grama. Journal of Range Management 23:63-66.

Torell, L. A., K. C. McDaniel, S. Cox, and S. Majumdar. 2008. Eighteen years (19902007) of climatological data on NMSU's Corona Range and Livestock Research Center. Las Cruces, NM, USA: New Mexico State University Agricultural Experiment Station Research Report 761. 20 p. Available at: http://aces.nmsu.edu/pubs/research/weather_climate/RR761.pdf. Accessed 21 June 2010

uS Department of Agriculture Soll Conservation Service. 1987. Potential natural vegetation, New Mexico: January 1978. New Mexico Interagency Range Committee Report 11. Ft. Worth, TX, USA: USDA-SCS-National Cartographic Center. [Distributed by Albuquerque, NM, USA: State Conservationist.]

Vallentine, J. F. 1990. Grazing management. San Diego, CA, USA: Academic Press. $533 p$. 